\title{
Scholarly study of primary schools of Pakistan: A case of Rajanpur District
}

\author{
Iftkhar Ahmad ${ }^{1}$, Dr Nadeem Iqbal ${ }^{2}$ \\ ${ }^{1}$ Indus International Institute DG Khan \\ ${ }^{2}$ Faculty of management Sciences, Ghazi University DG Khan \\ E-mail address: drnadeemiqbal1@gmail.com
}

Keywords: Supervision primary institutes, syllabus, moderate of lessons, fall out, presentation.

\begin{abstract}
The fundamental subject of the education is the serious investigation of primary schools of Tehsil Jampur (Pakistan). The study constructed on most important and less important bases. Principal information collected from blood relation, colonels, educators and scholars over opinion, survey, and consultation implements however subordinate statistics by go through collected works. A model of 200 scholars, 100 educators, 100 parentages and 30 colonels are a selection of by implementing stratified accidental sample enterprise. Qualitative and measurable skills used for the exploration of information. It is initiate that mainstream of the Supervision primary schools do not have suitable school structure and other elementary accommodations. Program of education is not absolute presented and employed in such departments. There is silent an argument on moderate of lessons between investors. The waster percentage is swelling therefore future and investigation is quite a challenge. The performance of educators and scholars remains improper. Parentages do not demonstration any attentiveness in the matters of institutes. Moreover, colonel seldom duty call and administer Control region primary schools. Going on origin of the conclusions, the object is round off with endorsements given at the end of paper.
\end{abstract}

\section{INTRODUCTION}

A fundamental role-play of Primary schools to make the people educated and cultured. In society, they set moral, efficient, honest, politically aware and social and language standards. The educational system started in primary schools goes around the philosophy, rational, sense, good point, tradition, custom, talent and familiarity of nation. The Country goes advancement whose primary school set up is firmly organized are technologically advanced and educated. Developing countries like Pakistan need to capitalize on efficiency and aptitudes of the advanced human principal through quality of primary education (Economic surrey of Pakistan, 2006-2007, p. 161). The quality and quantity of primary school education not only prepares youths for later educational levels but also provides them with the basic expertise necessary for the fruitful life. Development of human wealth can be only distant under through the quality of basic education.

Unfortunately, proper religious observation has not paid to improve the educational efficiency in Pakistan. Pakistan is still a long way from succeeding universal primary Enrolment (Pointed Lynd (2007). It is really very sad that present position of primary schools in Pakistan especially in rural areas of Tehsil Jam poor, is still very miserable, although that "the importance of education was fully realized soon after the establishment of Pakistan". Every continual government has always been a main concern for an increase in primary enrollment. It has also perceived that the basic education in the state of Pakistan interprets a miserable picture, considered by a high illiteracy rate, low primary enrolment, high dropout rates and the poor quality of education provided" (The Second Quarterly Report, p.129). Many children between 5 to 9 years of age are still not attending school. (D Lynd 2007)(P.11). Pakistan is in front of the dare of quality and quantity in the field of primary schools. In National education policy, 1992 give emphasis to those positive actions should take to raise the standard of primary education (Quality of primary education in Pakistan, 2003, p.9). Pakistan has still measured among those few countries in the world, which have lowest literacy rate, even with a number of inflated researches. It is very exciting 
to note that in the past twelve years the literacy rate giving to official rights have been recorded as annual increase of 1\% where as people has been swelling over 3\% every year (Dog arsons, 1998, p. 422). One-half of the people put an end to their primary schooling. A girl whose parents are not gratified with teacher is being present, regularity, manners and teaching is 5.5 times more likely to drop out (Gender gap in primary education, 2010). It should be painstaking that going up educational chances to the many though has expected devotion of policy organizers since long but has not attained yet, even a little bit.

\section{Purposes of research:}

The following objects put forward to paradigm the study.

1. Identify the situation and routine of primary schools of Tehsil Jampur.

2. Know that the involvement of teachers, students, officers and parents for the advancement of primary schools.

3. To propose the techniques and wealth to make primary schools more active.

\section{Research Questions;}

The following questions developed to attain goals and objects.

1. What is the genuine situation and presentation of primary schools?

2. What is the involvement of educators, scholars, parentages and colonels in the direction of the raise of primary schools?

3. How can the primary schools made more active?

\section{Review of Literature;}

Man has granted with the quality to deliberate. He has always been irrational about travel around the reality. Only the education makes him to think. A single is not always sensible to consider about what he learns in actuality he learns many things like expertise, assertiveness, traditions, the intellectual and the activities arrangement (Khalid, 2004, p.21). Education in authenticity is an intentional doings that guidance the communal for the wellbeing of the forthcoming age group. Education is as old as the human competition, all the same in passage of time its significance and goals have without doubt go through positive change. (Chandra) (2010) Rudimentary man was humble; his needs were incomplete, a small number of and controllable. Education was worth for pleasure of the desires of the body, food, clothing and accommodations. (Mammon, 2001, p.1) Man in the meantime his attendance on the earth has been motivated solid to walk just before development by coming out of the gloom.

These circumstances legalized the setting up of schools and the learning of truths (Khalid, 2004, p.21). The important work of schools is to take full advantage of the dimensions of each scholar. Today the central goal of school is to support a child how to think, what to think, how to develop the young awareness. If school is speculative to be developed then scholars will be its products and society a customer. If society eats manufactured goods more, naturally the call of scholars will increase; this will replicate the achievement and efficiency of schools. However, the situation of primary schools running in Pakistan especially in Tehsil Jampur is converse. Here the leading object of education is job only. The growing job loss percentage has critically artificial the quality and standard of primary school education. Furthermore, the new reading ability rate of Pakistan is 58\%, (Economic Survey of Pakistan 2011-12, p. 138), which means that $42 \%$ children do never have a chance of school. An excessive figure of children in inferior profits groups, for the most part rural and girl children never comprehensive primary school. National Education Policy2009 conditions that low admission rate is due to blood relation lack of self-confidence in public schools (p.7). There is a sequence of difficulties in education area in Pakistan that has instigated poor superiority and low admission of education (Financing of education in Pakistan, 2003 , p. 16). The basis of difficulties found in our education system is deficiency and insufficient 
public invest in. There is also the nonappearance of administration and controller. In many areas, schools and textbooks are accessible and educators are compensating, but they never report for work. These schools are calling ghost schools and educators are calling to be on certifications.

In addition, child labor remainders prevalent in Pakistan and global mortal rights groups have acknowledged "general" use of merged child labor there. Particularly in farming and fabric engineering (The Miss education of Pakistan, 2007). The Education, mostly primary school education is the birthright of all children. Its delivery is not only the legal responsibility of government but parentages and family unit are in the same way answerable. The Administration should harshly sanction that, illiteracy a communal offense. . A one who is not capable to speak and pen should not give national identity card. He should ban to come in the cities of the country. Schooling of primary institutes should understand focused on. It should encourage rational about thoughtful.

\section{Research methodology;}

Synthesis research method is implementing in this learning and information is collect-concluded assessment technique and opinion, feedback form and dialog implements. Educators, scholars, parentages and colonels are counting in the residents. A sample of 200 scholars, 100 educators, 100 parentages and 30 colonels are select from Government primary schools of Tehsil Jampur by approving stratified chance selection proposal. Qualitative and measurable procedures used for the examination of data. The tools planned giving to nine clear-cut variables of the learning. These include:

1. School structure and accommodations

2. Syllabus outline and application

3. Moderate of lessons

4. Dropout of schoolchildren

5. Analysis structure

6. Superiority of educator

7. Schoolchildren's presentation

8. Parentage support

9. Colonels' command

\section{FINDING AND DISCUSSION}

\section{School structure and accommodations}

Q. Do you think that most of the Primary schools have proper School structure and accommodations?

\begin{tabular}{|l|l|l|l|}
\hline S.N & State Container & Agreed\% & Disagreed\% \\
\hline 1 & Colonels & 23 & 77 \\
\hline 2 & Educators & 16 & 84 \\
\hline 3 & Scholars & 19 & 91 \\
\hline 4 & Parentages & 06 & 94 \\
\hline
\end{tabular}




\section{Analysis}

The maximum institutes deficiency the suitable structure and accommodations. They are not completely fitted with stuff and lessons substantial. In this regard, 94\% parentages said that most school has single room for five different classes. The room is overloaded and unlimited quantity of scholars does not treasure trove satisfactory space to take a seat and learning. Drinking water, electrical energy and chamber pot are absent in most of the institutes. Some institute does not have even school structure. Kids are receiving schooling beneath the gloom of sapling. Colonels comprise of $77 \%$ known that such school need elementary services and they made information to pull the devotion of higher establishments on this critical problem. Positively, such school grounds the failure of superiority and extent of learning. Educators $84 \%$ and scholars $91 \%$ jointly said that single room schools both should be close and given more classrooms and educators. These schools abolish the period and vigor of together scholars and educators. In these schools, scholars pick up immoral customs. The teaching only for one hour but they excess three hours impractically. They said that co-curricular actions are also the portion of learning but institutes do not have play area.

\section{Prospectus and its use}

Q. Do you think that syllabus outline is properly application in Primary Schools?

\begin{tabular}{|l|l|l|l|}
\hline S.N & State container & Agree $\%$ & Disagree \% \\
\hline 1 & Colonels & 34 & 66 \\
\hline 2 & Educators & 31 & 69 \\
\hline 3 & Scholars & 04 & 96 \\
\hline 4 & Parentages & 03 & 97 \\
\hline
\end{tabular}

\section{Analysis}

The educators $69 \%$, scholars $96 \%$, Parentages $97 \%$ and colonels $66 \%$ are uninformed and oblivious of syllabus. When they do not know about the construction and features of syllabus, what will be its application? They make the waste of syllabus. They make no alteration between course outline and syllabus. Near them syllabus is simply the traditional of paperwork. Nobody of them can convey the goals and purposes of primary education as defined in learning programs. They did not tell everything about lessons method and assessment. They used assessment and analysis in the equal sense. On the other hand, they are not fulfilling with paperwork. Parentages said that paperwork is not career adapted. Colonels told that paperwork are out out-of-date. The difficulties of culture are fluctuating day by day in globalization but paperwork goes on similar for the log time. Educators blunt out that the paperwork is not giving to rational age of kids. At primary flat paperwork should be cool and in physical form. There should not be intellectual data. Scholars protested that paperwork is not exciting and good-looking.

\section{Delivering of lessons}

Q. Do you think that Model of lesson should be English at primary school level?

\begin{tabular}{|l|l|l|l|}
\hline S.N & State container & Agree\% & Disagree\% \\
\hline 1 & Colonels & 73 & 27 \\
\hline 2 & Educators & 24 & 76 \\
\hline 3 & Scholars & 11 & 89 \\
\hline 4 & Parentages & 94 & 06 \\
\hline
\end{tabular}




\section{Analysis}

The opinions on the subject of standard of lessons similarly distributed between investors. Colonels including 73\% and 94\% parentages were in indulgence of English and 76\% educators and $89 \%$ scholar has sustained native linguistic as a standard of teaching. Educators said that kids impression very tough to know the matter in the external linguistic. It abolishes originality and rational intellectual. Scholars said that education is easy in mother language. Colonels said that our scholars have to look universal antagonism. They can make it on universal glassy if they get schooling in universal linguistic. Parentages said that for decent career scholars must have understanding over English linguistic.

\section{Idler children}

Q. Do you think that dropout is growing in idler children at primary school level?

\begin{tabular}{|l|l|l|l|}
\hline S.N & State container & Agree\% & Disagree\% \\
\hline 1 & Colonels & 69 & 31 \\
\hline 2 & Educators & 79 & 21 \\
\hline 3 & Scholars & 88 & 12 \\
\hline 4 & Parentages & 80 & 20 \\
\hline
\end{tabular}

\section{Analysis}

On the problem of dropout, the schoolchildren are responsible both extra. Parentages $80 \%$ accountable are educators and colonels for this. The severe outlook of educators and feeble command of colonels mark the kid's permission the school. Educators involving $79 \%$ are of the attitude that Parentages deficiency of attentiveness to tutoring grounds the kids to stretch active knowledge. These parentages wish their kids to drive on labor quite than institute. This approach of parentages bases in the growth of dropout. Colonels 69\% made educators and parentages similarly accountable for drop out. Scholars want incentive for superior learning and educators and parentages do not stimulate scholars to need developed learning. This absence of incentive growth makes dropout. Scholars $88 \%$ thought that they want support of parentages, educators and colonels but nobody of them is prepared to work together. This performance of these investors reasons dropout of scholars.

\section{Assessment structure}

Q. Are you gratified with the analysis structure at primary school level.

\begin{tabular}{|l|l|l|l|}
\hline S.N & State containers & Agree\% & Disagree\% \\
\hline 1 & Colonels & 73 & 27 \\
\hline 2 & Educators & 60 & 40 \\
\hline 3 & Scholars & 84 & 16 \\
\hline 4 & Parentages & 73 & 27 \\
\hline
\end{tabular}

\section{Analysis}

Combination replies were gathering on the interrogation of analysis structure. Parentages $(73 \%)$ cause problems this assessment structure. Colonels $(73 \%)$ harassed six-month analysis but educators $(60 \%)$ chosen three month analysis. Scholars $(84 \%)$ supposed that they work hard when inspection comes near. In yearly analysis they work hard once in year. As a result, exanimation should be regular to retain scholars busy in appraisal round the year. 


\section{Superiority of educator}

Q. Are you gratified with the Superiority of educator at primary school level.

\begin{tabular}{|l|l|l|l|}
\hline S.N & State container & Agree \% & Disagree\% \\
\hline 1 & Colonels & 17 & 83 \\
\hline 2 & Educators & 26 & 74 \\
\hline 3 & Scholars & 19 & 81 \\
\hline 4 & Parentages & 03 & 97 \\
\hline
\end{tabular}

\section{Analysis}

The shareholders continued displeased with superiority of educators. Parentages 97percentage, $81 \%$ of scholars, $74 \%$ of educators and $83 \%$ of colonels, sustained the report. Parentages said that educators are taking on importance source. They are generally inattentive from institutes or arise for a very short time. They take no attention in the scholars' schooling. Scholars study very tiny from faculty. Scholars exposed their terror of physical penalty by educators. They told that educators select corporal penalty over incentive. They are psychologically distressed in arrears to strict boldness of educators. Colonels also approved that there are impression educators and institutes. These educators have change to the governmental provision. They are not in station to take achievement counter to these educators. They have defective panels. These educators are the in charge of failure of schooling. Educators said that they expression the shortage of amenities. There is a particular educator to communicate five dissimilar periods at a time in a single room. When the educator communicates one class, mechanically four other classes will have to hurt. This is why an educator cannot up boost the customary of teaching. To regulator and preserve punishment in the classroom, he has to act severely. He does not love of corporeal penalty but he does so only to keep the other classes under control. Scholars of other sequences inactive in the same room make sound and get in the way the educator to teach a class. In addition, teachers grow less payment and people do not give owed admiration to educators. Most educators are disheartened and depressed.

\section{Schoolchildren's presentation}

Q. Are you gratified with the performance of students Schoolchildren's presentation at primary school level.

\begin{tabular}{|l|l|l|l|}
\hline S.N & State container & Agree\% & Disagree\% \\
\hline 1 & Colonels & 43 & 57 \\
\hline 2 & Educators & 23 & 77 \\
\hline 3 & Scholars & 11 & 89 \\
\hline 4 & Parentages & 01 & 99 \\
\hline
\end{tabular}

\section{Analysis}

The interested party consists of $57 \%$ colonels, $99 \%$ parentages, $77 \%$ educators and $89 \%$ of scholars were not happy with the routine of scholars. Parentages put responsibility for colonels and educators. Due to deficiency of administration, educators are irregular and rough. They do not broad their passages. This makes kids fragile in teaching. Educators make paternities guilty for kids' worse concert. Paternities do not compensation any responsiveness on the learning of their youngsters. Colonels call the deficiency of impulse the central source of humble concert of scholars. 
They understood that scholars are innocent. They do not see approximately decent or corrupt and right or wrong. Tutors and paternities have to develop them cognize the real portrait of learning. Schoolchildren said that institutes are not striking. The averment of schools is drab. They are not intent in receiving tutoring in such pain giving tradition.

\section{Parent's support}

Q. Are you gratified with the parents support at primary school level.

\begin{tabular}{|l|l|l|l|}
\hline S.N & State container & Agree\% & Disagree\% \\
\hline 1 & Colonels & 03 & 97 \\
\hline 2 & Educators & 17 & 83 \\
\hline 3 & Scholars & 19 & 81 \\
\hline 4 & Parentages & 37 & 63 \\
\hline
\end{tabular}

\section{Analysis}

Not all the participants with 97\% colonels, $83 \%$ educators, $81 \%$ scholars and $63 \%$ parentages were mollified with support of parentages. Colonels communicated that Parentages are uneducated and do not proceeds a dynamic concern in their kids' schooling. They also ignore take part in the activities of school. It should be the responsibility of close relative to explosion the complications of department. They should make criticize against those instructors who are not steady and on time. Learners said that their paternities are illiterate. They drive them on labor later institute times. They do not enquire rounded institute problems. Educators pointy out that paternal at no time visit the institute. They reward no crown on the troubles of families in conservatory and out of department. The conservation of regular of learning is incredible short of the support of parental because scholars spend their maximum time in the control of blood relate. Paternities believed that they are standing by to work together with educators and colonels. They held responsible that tutors and colonels at no time communication or invitation them in the institute. They more assumed that colonel do not take action in contradiction of unforeseen educators. They believed that they refer their families on labor due to their deficiency of money.

\section{Officer's command}

Q. Are you satisfied with the process of supervision by officer's command at primary school level?

\begin{tabular}{|l|l|l|l|}
\hline S.N & State container & Agree\% & Disagree\% \\
\hline 1 & Colonels & 39 & 61 \\
\hline 2 & Educators & 06 & 94 \\
\hline 3 & Scholars & 04 & 96 \\
\hline 4 & Parentages & 03 & 97 \\
\hline
\end{tabular}

\section{Analysis}

The participants involving $61 \%$ colonels, $97 \%$ parentages, $96 \%$ scholars and $94 \%$ educators told that accurate administration is the depth of in effect society. The institute that blunders the emblematic observation will degeneration day by day. Paternities and scholars mutually assumed that colonels not official visit the neither institutes nor takings achievement beside educators who habitually go on inattentive from institutes or arise for a very minor. Educators thought that colonels do not precede concern in the hitches of institute. Colonels explicated that they have partial commands and 
funds. They do not have the authority of complex and intensity. They even privation the supremacy of removal of any educator. They are only the communiqué station between administration and institute. They understood that scholars' hitches can resolve and regular of learning will develop if all the participants' effort organized.

\section{RECOMMENDATIONS}

1. The school structure and accommodations mirrors upon the character of scholars. Nicelooking schools make the character of scholars more beautiful. Institutes held to be nicelooking if they have proper structure, tools, play area, cold water, electricity, trained and regular educators, expert supervisors, interested scholars and supportive parentages. All the schools should be prepared with suitable structure and accommodations. These schools should found within easy reach of scholars.

2. The parentages, educators, scholars and colonels are ignorant of syllabus. They do not know the fundamentals of syllabus. In such case, the proper application of syllabus is incredible. It is, as a result, important for policy makers that they should arrange the pamphlets of syllabus and make sure the disposal of pamphlets at school. More over there should be meetings and conferences on syllabus outline and application in which parentages, educators, scholars and colonels should requested to take part. The books should improve from spell to spell.

3. The Moderate of lessons has gone on prepare of contention between doctors. Common of doctors favor native language for standard of teaching. Even the opinions of colonels, parentages, educators and scholars are separated and dissimilar. Educators and scholars are alarmed right with teaching and learning. Their views about moderate of lessons have more significance. More over Japan, Russia, China and France etc. are giving education in their own language. When their education is progressive why we cannot make improvement. It would improve if moderate of lessons becomes native language. English as a subject should be educated from class one.

4. There are many motives of dropout but the most vital motive is strict approach of parentages, educators and colonels towards scholars. Their conversation is penalty. They close your eyes to stimulus. Rousseau accurately assumed that they have made schools worse than lockup. Children are acquitter; they need understanding, Love, proper control, advising and motivation it is, as a result, vital for plan manufacturers that they should abolish all procedures of penalty. They should indorse incentive, help and self-confidence in the schools. They should make school and syllabus more beautiful.

5. It has converted the fashion that students work hard few days before inspection. They read purely for inspection. Scholars also work hard one time in year because the inspection taken one time in year. They go on unfamiliar beforehand inspection and disremember next exanimation. They learn the factual only for few days. This design of inspection has demolished the sympathetic and imagination of students. In future, to be clear of these problem policy makers should familiarize inspection after every three month and after every inspection, there should be fifteen days leave. The sequence should be summary to threemonth program of study. This arrangement of inspection will moderate the problem of long sequence and learners will revel in the learning, inspection and vacation. After vacation, they will renew for next term.

6. The educators conquer the essential place in the school the superiority of school learning is the through significance and result of the superiority of educators. The below par competent educators and extraordinary teacher-student relations, insufficient lessons resources and outdated schooling techniques are the central origins of low class learning that often teaches little or no real education. As a result, it is important that procedure manufacturers should make sure quality work over instruction and suitable training to educators. Educators should be extremely competent. Their ethical should enhance through suitable enrolment, earnings, and motivations, working environments, boost and complete skilled growth. 
7. The pupils are acquittal. They are impartial similar to fresh factual. Educators, parentages and field marshal have to give them final outline. They are impartial comparable computer, which elasticity available set giving to feedback. The global presentation of pupils hinge on upon the feedback that they accept in the school and society. The essential work of institutes and people must be to make best use of the ability of both pupils. They must specified suitable ether, incentive and supervision. The educators, close relative and soldier of rank must be very caring and considerate. Here must be no signal of penalty. The sequence must grow giving to intellectual stage of schoolchildren.

8. Furthermost parentages are uneducated and oblivious. They do not recognize the significance of schooling. They favor to refer their kids to labor comparatively than institute. They make no support in the elevation of schooling. These parentages must stimulus and responsiveness. The meetings and discussions must apprehend for these parentages. A working group should design to see these blood relations by the side of their households and in work apartment. This commission must complete in authority for the stimulus and backing of the blood relation about the schooling of their kids.

9. General Majors / administrators are educators by occupation. They do not identify the fundaments of supervision and observation. Furthermore, they do not authorize to take critical conclusions approximately the advancement of institute and instruction as an entire. They do not have the authorities of developed and fervor. Even transferal of educators is challenging for them in constituency Administration. The politically aware immersion discourages those beforehand educators, scholars and parentages. It essential that colonels must allotted independently from end to end directive. Instructors must not give direction supports. The supremacy of complex and ardor should give to these captains. The too much politically aware connection in the teaching should severely reject. These colonels should mark in authority for appropriate reading ability and superiority of instruction.

\section{Referencess}

[1] Baluch, M. \& Shahid, S. (2008). Determinants of enrollment in primary education: A case study of district Lahore. Pakistan Economic and Social Review, 46(2). Retrieved from http://pu.edu.pk/images/journal/pesr/PDF-

FILES/6\%20Baluch\%20Lahore\%20Edu\%20Study.pdf

[2] D. Lynd (2007). The Education System in Pakistan: Assessment of the National Education Census .UNESCO Islamabad, Pakistan. Retrieved from

http://www.teachereducation.net.pk/files/sa4.pdf Dogarsons (1998). Universal aptitude tests (Is ted.). Al-Karim Market Urdu Bazar, Lahore.

[3] Economic Surrey of Pakistan (2006-2007). An Accountancy publication. Retrieved from www.accountancy.com.pk

[4] Education in Pakistan (2007, November 27). Retrieved from http://www.r4e.org/education/downloads/Education\%20in\%20Pakistan.pdf

[5] Financing of education in Pakistan (2003, May:16). Ministry of Education, Government of Pakistan in collaboration with UNESCO, Islamabad. Retrieved from http://www.moe.gov.pk/study.pdf

[6] Gender gap in primary education (2010). North West Frontier Province. Retrieved from cietpakistan@ciet.org Khalid, M. T. (2004).Education Part I. Carvan Book House, Lahore.

[7] Khan, A. H. (1997). The education in Pakistan: Fifty years of neglect. The Pakistan Development Review, 36(2). Retrieved from http://www.pide.org.pk/pdf/PDR/1997/Volume4/647-667.pdf

[8] Lynd, D. (2007). The education system in Pakistan: Assessment of the National Education Census, UNESCO Report, Islamabad, Pakistan. Memon, G. R. (2001). History of education. Mataba Freedi Urdu College Lahore. 
[9] National education policy 2009. Retrieved from http://www.moe.gov.pk/nepr/new.pdf Chandra, P. (2010). International encyclopaedia of education. Retrieved from http://www.waterstones.com/waterstonesweb/products/p+chandra/international+encyclopaedia +of+education/5658873/

[10] Pakistan Economic Survey 2011-12 (21012, June 1), Retrieved from http://finance.gov.pk/survey/chapter_12/10-Education.pdf

[11] Quality of primary education in Pakistan (2003, May). Ministry of Education, Government of Pakistan in collaboration with UNESCO Office, Islamabad. Retrieved from http://www.moe.gov.pk/soq.pdf

[12] The Miseducation of Pakistan (2007). LLeessssoonn PPllaann//GGuuiiddeebbooookk. Retrieved from www.choicesvideo.net

[13] The Second Quarterly Report for FY04. Retrieved from http://www.sbp.org.pk/reports/quarterly/fy04/scq/Special\%20Section\%201\%20Basic\%20Education\%20in\%20Pakistan. 